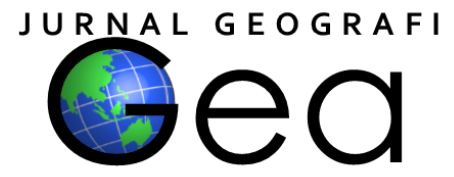

\title{
SURFACE RUNOFF MANAGEMENT MODEL OF BANDUNG REGENCY THROUGH REMOTE SENSING ANALYSIS
}

\author{
Dede Sugandi1, Riki Ridwana ${ }^{2}$, Arif Ismail ${ }^{3}$, Jalu Rafli Ismail1', Rafi'i Diva Sephana ${ }^{2}$ \\ ${ }^{1}$ Geography Education Study Program, Universitas Pendidikan Indonesia \\ ${ }^{2}$ Geographic Information Science Study Program, Universitas Pendidikan Indonesia \\ ${ }^{3}$ Survey Mapping and Geographic Information Study Program, Universitas Pendidikan \\ Indonesia \\ 1dedesugandi@upi.edu ,2rikiridwana@upi.edu ,3arifismail@upi.edu, 1jalugeo@upi.edu , \\ ${ }^{2}$ rafiisephana@upi.edu
}

\begin{abstract}
Flood is caused by surface runoff, therefore controlling the surface runoff is necessary especially on built areas. This research aims to analyze the width, calculate the volume of surface runoff and analyze the model of infiltration wells on built areas in Bandung Regency. The method implemented in this research is experimental. This method was carried out while analyzing rainfall on built areas samples, which is house building. Land use was analyzed through Landsat 8 imagery in the year 2019. Rainfall volume was calculated by equation $V=h \times 1$. Meanwhile, the volume of the infiltration well was calculated by equation $\mathrm{V}=\mathrm{h} \times \mathrm{k}$. The result of the 2019 Landsat imagery analysis shows that $19.01 \%$ of total watersheds in Bandung Regency or as much as $1382.13 \mathrm{~km} 2$ are built areas. The highest rainfall in a total of $0.02431 \mathrm{~m}$ occurred in October on the area of 197.67 $\mathrm{m} 2$ and became a surface runoff of $377,534 \mathrm{~m} 3$. In a house building, as-built area example, as wide as $90 \mathrm{~m} 3$, the amount of $2.19 \mathrm{~m} 3$ rainwater needed to be infiltrated. The infiltration well model is a management model on each built area, so that rainwater on built areas would not be turned into surface runoff.
\end{abstract}

Keywords: Landsat imagery, surface water, built areas, infiltration wells.

\section{INTRODUCTION}

Bandung Regency lies in the Bandung Basin. The Bandung Basin is flowed by $\mathrm{Ci}$ Tarum with numerous tributaries. All tributaries disembark into $\mathrm{Ci}$ Tarum which is located in Bandung Regency. Other than tributaries from different cities, Bandung Regency is flowed by four tributaries, namely $\mathrm{Ci}$ Widey, Ci Sangkuy, Ci Rasea, and Ci Tarik. The flow of all tributaries is concentrated in Bandung Regency, so that it will eventually overflow in sub-districts of Dayeuhkolot, Baleendah, and Bojongsoang. The occurrence of floods in these areas is generally similar as
Baleendah and Dayeuhkolot had experienced large river floods since 2005.

Population movement between areas has been affecting the environmental ecosystem. As stated by Ischak (2001) and Rai (2017) that, in addition to improving a better life, urbanization affects the occurrence of environmental damage. The process of urbanization is supposed to be a way of improving lives, instead of damaging the environment out of fulfilling human needs (Sugandi \& Pascawijaya, 2020b). Environmental damages will affect lives, for instance on the food resources scarcity (Amri, 2011). Cities around the world face many environmental health challenges 
including contamination of air, water, and soil, traffic congestion and noise, and poor housing conditions exacerbated by unsustainable urban development. The existing causes of damage to the environment due to urbanization and Urbanization: Environmental conditions in cities have gradually deteriorated due to the rapid growth of the cities (Vardoulakis et al., 2016).

Urbanization affects statistically the conversion of agricultural land to build areas (Nuraeni et al., 2017). Urban development causes the decrease of public service facilities, environmental degradation, slum areas, pollution, and minimum access of land for migrants (Tjiptoherijanto, 1999). Land use in studied areas in 2016 was dominated by human settlements (Wijaya \& Susetyo, 2017). These areas have been experiencing interaction between humans and their environment, especially in building public facilities, which could potentially change the function of land as a unit of hydrologic process, the land that initially absorbs water turns to be impermeable (Suprayogi et al., 2019). Other components that affect the ecosystem are slope and soil. The increase of slope gradient affects the generation of surface runoff (Danáčová et al., 2017). Thus, the increase of urbanization without sound management would increase flood risks and negatively impact the loss of life and property that has to be mitigated (Ahiablame \& Shakya, 2016; Iskandar \& Sugandi, 2015).

Population growth increases the need for land causing its ability to decrease (Noeraga et al., 2020). Growing numbers of the population are the factor of changes in land use, while its space remains the same. Consequently, population movement becomes inevitable (Raharja, 2012). To analyze land use in a fifteen years range, Landsat imagery is a proper source for further analysis through remote sensing and geographic information system techniques (Bianchin \& Bravin, 2008). The result of the analysis shows there is a shift in built areas spaces. Expansion of the built-up area was increasing the surface runoff in the Bandung basin and urban waterlogging stems from coverage with impervious surfaces (Sugandi \& Pascawijaya, 2020a). In analyzing these phenomena, remote sensing can present spatial information relating to the physical features of specific areas (Susiati \& Subagio, 2017). In this research, remote sensing techniques are utilized to give information on land-use changes, especially in built areas. Built areas expansion has caused numbers of land conversions that also expand impermeable surfaces which minimize infiltration, decrease groundwater, as well as increase surface runoff (Maria \& Lestiana, 2014)

Case example of urban flooding or flood caused by built areas expansion occurred in Narok Town, Kenya (Marie Mireille et al., 2019). In addition, Ardianto et al. (2014) stated that areas with dense populations, dominated by settlements and business centers shall be prioritized for prevention. Areas with the aforementioned characteristics are likely to experience urban flooding. The urban flooding in cities is mainly in the form of flash floods and waterlogging of streets due to high-intensity short spell rainfall (Bansal et al., 2015). The result of land-use changes mostly to settlements is the increase in surface flow debit which tends to turn into surface runoff (Nofrizal, 2019).

On flood analysis, land use, specially built areas, is considered as an environmental component that is prone to changes. Built areas create impermeable surfaces that decrease the infiltration process. As stated by Ibeje et al. (2018) that land use can affect natural ecological processes such as infiltration. For this reason, remote sensing analysis is necessary to examine the effect of land use on environmental sustainability. In the other words, Environmental sustainability has to support the sustainability of life and development. Hence, conservation must 
be done to support the attempt of preserving the sustainability of the ecosystem (Sugandi, 2014). Thus, overcoming floods through managing surface runoff could be done by designing and implementing Permeable Pavement (PP) to mitigate urban waterlogging problems (Chen et al., 2021). A method to manage surface runoff is called the zero runoff method which functions as rain intensity, reservoir, retention pond, and catchment area which are framed into utilizing and streaming activities (Sarbidi, 2015). All of these implementations are done to increase infiltration.

In this research, the conservation model to manage surface runoff as the way to prevent flood is aimed to

a) Analyzing the width of land use and built areas on watersheds in Bandung Regency through remote sensing techniques.

b) Analyzing the management of surface runoff on built areas located on watersheds in Bandung Regency through remote sensing techniques.

c) Analyzing surface runoff management models on built areas located on watersheds in Bandung Regency through remote sensing techniques.

\section{RESEARCH METHOD}

This research is conducted to analyze rivers of Ci Widey, Ci Sangkuy, Ci Rasea, and $\mathrm{Ci}$ Tarik that flow in Bandung Regency. An experimental method is implemented in this research and is supported by remote sensing analysis. Trials of the method were carried when rain occurred by blocking surface runoff that flowed from outside of house buildings. The rainfall then flowed into the infiltration well. The width of each classified land use was analyzed through Landsat 8 imagery. Analysis technique implemented to examine intensity and rain volume is calculated on built areas width and applied to house building as its example. To calculate the intensity, the equation is developed from a rational method as follow

$$
\begin{aligned}
\mathrm{I}=\mathrm{h} \times \mathrm{W} \\
\mathrm{I}=\text { rain intensity } \\
\mathrm{h}=\text { precipitation rate } \\
\mathrm{W}=\text { time (hour). }
\end{aligned}
$$

In order to calculate rainfall volume as well as well volume and containment ability proportional to rainfall volume, the implemented equation is

$$
\begin{aligned}
\mathrm{V}=\mathrm{t} & \times \mathrm{k} \\
\mathrm{V} & =\operatorname{Volume}\left(\mathrm{m}^{3}\right) \\
\mathrm{T} & =\text { precipitation rate }(\mathrm{m}) \\
\mathrm{k} & =\text { width of built area }\left(\mathrm{m}^{2}\right)
\end{aligned}
$$

\section{RESULTS AND DISCUSSION}

\section{Results}

\section{Land use}

Land use data was taken from Landsat 8 imagery which was further analyzed by remote sensing techniques. The result of the analysis is classified into; agriculture, inland fisheries, plantation, moorland, and non-agriculture. Ideally, albeit the use of these land classes is to meet human needs, the environmental balance shall also be enhanced. As the population grows, land-use changes. Whether forests changed into agricultural land, or into inland fisheries, plantations, moorland, and human settlements. Those changes will influence soil functions. The occurring dominant change is the change from forest to build areas (human settlements), which causes the soil to be impermeable. During rainfall on this built surface, rainfall will not permeate through the soil, instead will be formed as surface runoff. Surface runoff moves toward the river and is concentrated on the impermeable land causing the river to overflow. Those rivers in Bandung Regency are Ci Widey, Ci Sangkuy, Ci Rasea, and Ci Tarik, which flows through the regency. The result of Landsat 8 analysis showed in Figure 1 as follows.

Land use influences surface runoff debit and infiltration rate. Surface flow 
and infiltration rate depend on land use. Thus, to overcome floods, the surface flow should be controlled by increasing the infiltration rate. The amount of surface runoff needs to be calculated on a land area from rain occurrence in each land use. The width of each land use is based on Landsat 8 image analysis shown in Table 1.

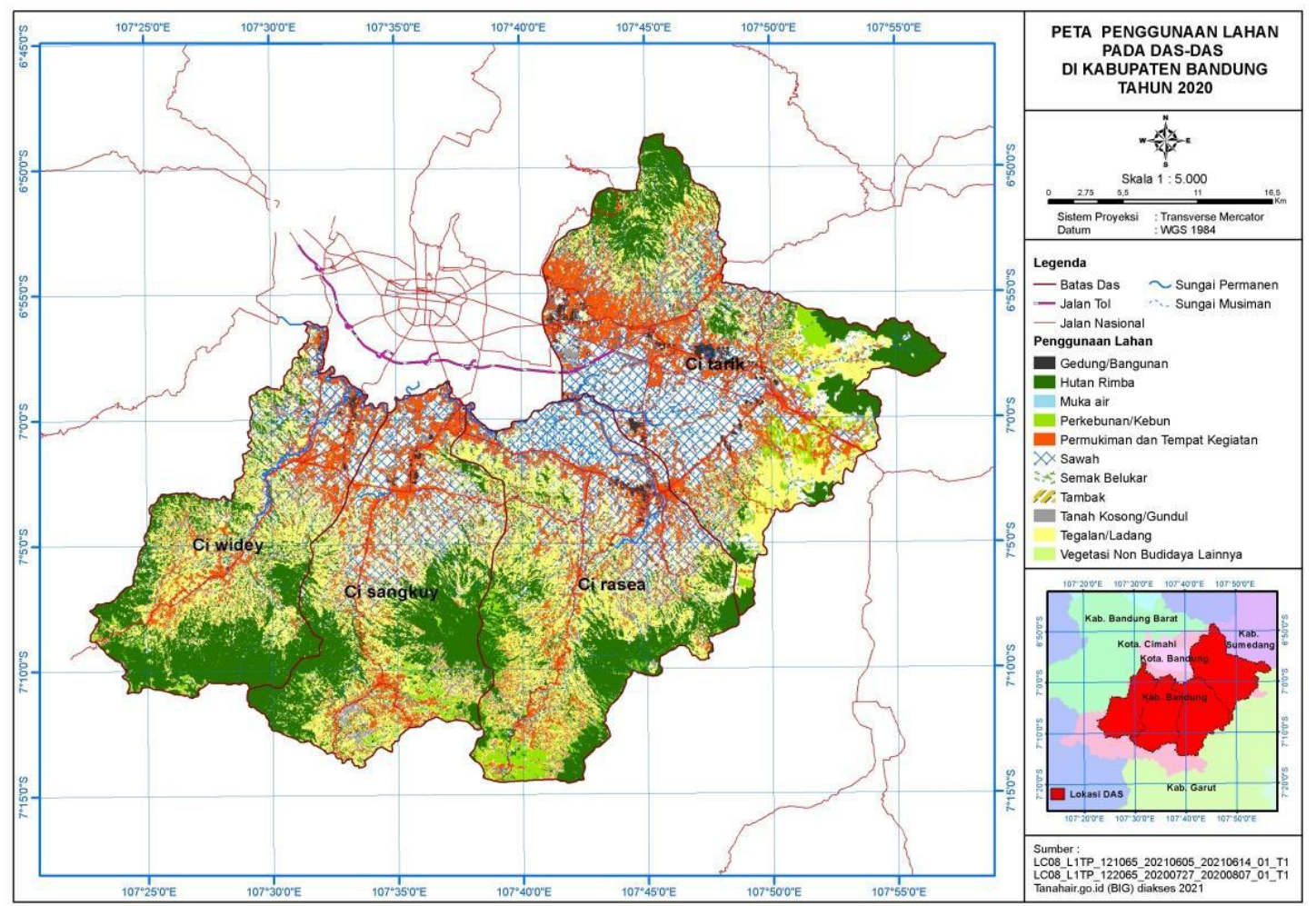

Figure 1. Land use map on watersheds in Bandung Regency

Table 1. Slope Gradient Classification and Scoring

\begin{tabular}{|c|c|c|c|c|c|c|c|c|c|c|}
\hline \multirow[b]{2}{*}{ Land use } & \multicolumn{2}{|c|}{ Ci Widey } & \multicolumn{2}{|c|}{ Ci Sangkuy } & \multicolumn{2}{|c|}{ Ci Rasea } & \multicolumn{2}{|c|}{ Ci Tarik } & \multicolumn{2}{|c|}{ Total } \\
\hline & $\begin{array}{c}\text { area } \\
\left(\mathbf{k m}^{2}\right)\end{array}$ & $\%$ & $\begin{array}{c}\text { area } \\
\left(\mathbf{k m}^{2}\right. \\
)\end{array}$ & $\%$ & $\begin{array}{c}\text { area } \\
\left(\mathbf{k m}^{2}\right. \\
)\end{array}$ & $\%$ & $\begin{array}{c}\text { area } \\
\left(\mathbf{k m}^{2}\right. \\
)\end{array}$ & $\%$ & $\begin{array}{c}\text { area } \\
\left(\mathbf{k m}^{2}\right)\end{array}$ & $\%$ \\
\hline Pond & 0.56 & 0.27 & 2.21 & 0.73 & 0.72 & 0.20 & 0.02 & 0.01 & 3.51 & 0.25 \\
\hline Shrubs & 1.88 & 9.51 & 5.27 & 5.27 & 3.26 & 0.89 & 20.40 & 4.69 & 30.81 & 2.23 \\
\hline Buildings & 2.29 & 0.82 & 2.05 & 2.05 & 3.34 & 0.91 & 9.30 & 21.61 & 16.98 & 1.23 \\
\hline Forest & 99.57 & 35.91 & 90.12 & 29.65 & 80.37 & 21.96 & 79.93 & 18.38 & 349.99 & 25.32 \\
\hline Plantation & 3.02 & 1.09 & 7.68 & 2.51 & 17.31 & 4.73 & 15.08 & 3.47 & 43.09 & 3.12 \\
\hline Settlements & 41.77 & 15.06 & 51.09 & 16.81 & 58.92 & 16.10 & 94.00 & 21.61 & 245.78 & 17.78 \\
\hline $\begin{array}{l}\text { Empty/wastela } \\
\text { nd }\end{array}$ & 4.28 & 1.54 & 9.87 & 3.25 & 10.96 & 2.99 & 12.13 & 2.79 & 37.24 & 2.69 \\
\hline $\begin{array}{l}\text { Irrigated } \\
\text { farmland }\end{array}$ & 46.91 & 16.91 & 63.17 & 20.79 & 83.37 & 22.78 & 120.94 & 27.81 & 314.39 & 22.75 \\
\hline Moorland & 77.03 & 27.78 & 72.52 & 23.86 & 107.72 & 29.43 & 83.14 & 19.12 & 340.41 & 24.63 \\
\hline Total & 277.30 & 100 & 303.92 & 100 & 365.98 & 100 & 434.93 & 100 & 1382.13 & 100 \\
\hline
\end{tabular}


Soil has a function as a waterabsorbent. Due to human activities on utilizing its land, soil function changes. Land uses that change soil functions are; built areas, namely; settlements and roads, office complexes, and public facility buildings. Those built areas change soil function to be impermeable. When rain falls onto built areas, the rainfall would not be absorbed, yet formed as surface runoff. In this study area, built areas are classified through Landsat image analysis as shown in Figure 2.

The result of image analysis shows that built areas that cause soil to be impermeable are public facility buildings, roads, settlements. The width of each built area is classified as above shown in Table 2 .

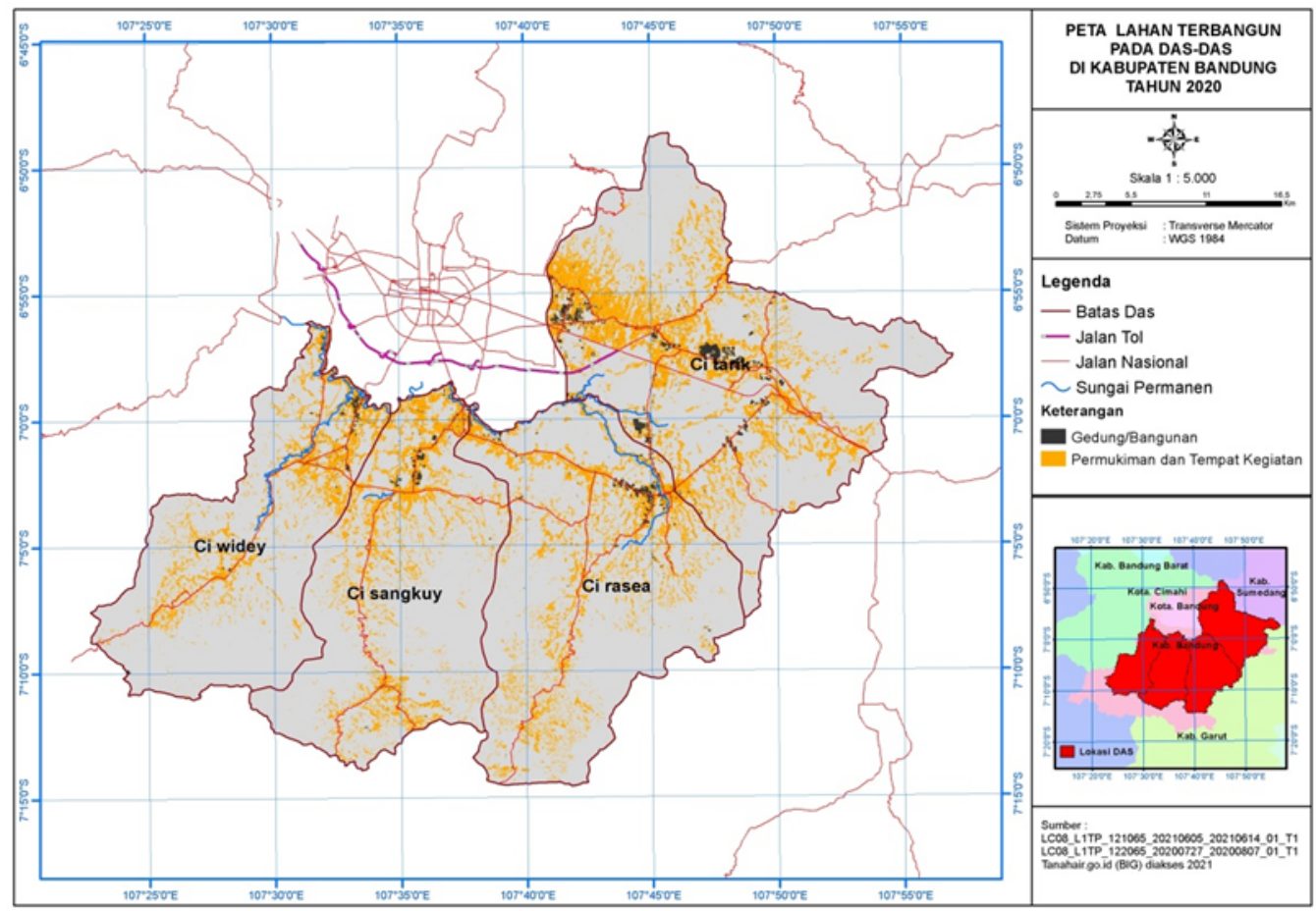

Figure 2. Map of Built Areas on Watersheds in Bandung Regency

Table 2. The width of built areas on Watersheds in Bandung Regency

\begin{tabular}{|c|c|c|c|c|c|c|c|c|c|c|}
\hline \multirow{2}{*}{ Built areas } & \multicolumn{2}{|c|}{ Ci Widey } & \multicolumn{2}{c|}{ Ci Sangkuy } & \multicolumn{2}{c|}{ Ci Rasea } & \multicolumn{2}{c|}{ Ci Tarik } & \multicolumn{2}{c|}{ Jumlah } \\
\cline { 2 - 12 } & $\begin{array}{c}\text { area } \\
\left(\mathrm{km}^{2}\right)\end{array}$ & $\%$ & $\begin{array}{c}\text { area } \\
\left(\mathrm{km}^{2}\right)\end{array}$ & $\%$ & $\begin{array}{c}\text { area } \\
\left(\mathrm{km}^{2}\right)\end{array}$ & $\%$ & $\begin{array}{c}\text { area } \\
\left(\mathrm{km}^{2}\right)\end{array}$ & $\%$ & $\begin{array}{c}\text { area } \\
\left(\mathrm{km}^{2}\right)\end{array}$ & $\%$ \\
\hline Buildings & 0.27 & 0.1 & 0.52 & 0.17 & 0.44 & 0.12 & 2.31 & 0.52 & 4.45 & 2.25 \\
\hline Settlements & 23.09 & 8.47 & 19.53 & 6.41 & 42.77 & 11.66 & 66.28 & 15.01 & 193.22 & 97.75 \\
\hline Total & 23.36 & 8.57 & 20.05 & 6.58 & 43.21 & 11.78 & 68.59 & 15.53 & 197.67 & 100 \\
\hline
\end{tabular}

Table 1 shows-built areas on watersheds in Bandung Regency have a width of $262.78 \mathrm{~km}^{2}(19.01 \%)$ from the total width of $1382.13 \mathrm{~km}^{2}$. On these built areas, flows of rainwater potentially turn into surface runoff, meanwhile, evaporation on these areas is relatively small, therefore it is not reviewed. Figure 2 shows that built areas span onto the upstream. The river upstream in this area was formed morphologically by mountains and hills as a catchment area originally as forests but currently has been changed into built areas. Built areas share the largest amount of surface water from the river upstream.

\section{Surface Runoff}

In this study area, the rivers upstream are morphologically shaped by 
mountains and are supposed to be forest areas for their function as catchment areas. During the rain, parts of rainfall will be infiltrated and the other flows as surface runoff. Either absorbed or flows will depend on soil function. If the infiltration is high, then surface runoff flows on the soil surface will be low. It is directly proportional as the infiltration is low, then surface runoff on the soil surface is big. The average rainfall in this study area was taken from two rain stations as shown by Table 3 .

Table 3. Monthly Average of Rainfall Year 2009 - 2018

\begin{tabular}{|l|c|c|c|c|c|c|c|c|c|c|c|c|}
\hline \multicolumn{1}{|c|}{ Station } & Jan & Feb & Mar & Apr & May & Jun & Jul & Aug & Sep & Oct & Nov & Dec \\
\hline Cisondari & 142.1 & 170.2 & 158.6 & 151 & 152.6 & 50.7 & 26.2 & 22.4 & 40.2 & 76.3 & 168.4 & 192.3 \\
\hline Cileunca & 241 & 268.7 & 266.8 & 265 & 133.8 & 57.9 & 35 & 37 & 52.7 & 118.2 & 292 & 336.9 \\
\hline Rainfall (mm) & 191.55 & 219.45 & 212.7 & 208 & 143.2 & 54.3 & 30.6 & 29.7 & 46.45 & 97.25 & 230.2 & 264.6 \\
\hline Rain days & 16 & 16 & 15 & 16 & 7 & 3 & 2 & 2 & 2 & 4 & 13 & 15 \\
\hline $\begin{array}{l}\text { Rain/days } \\
\text { (mm) }\end{array}$ & 11.97 & 13.72 & 14.18 & 13 & 20.46 & 18.1 & 15.3 & 14.85 & 23.23 & 24.31 & 17.71 & 17.64 \\
\hline $\begin{array}{c}\text { Rain intensity } \\
\text { mm/hour }\end{array}$ & 0.50 & 0.57 & 0.59 & 0.54 & 0.85 & 0.75 & 0.64 & 0.62 & 0.97 & 1.01 & 0.74 & 0.74 \\
\hline
\end{tabular}

The amount of rainfall in a year on watersheds in Bandung Regency is separated into the rainy season and dry season. Seasons are classified based on precipitation rate. The season is classified as the dry season when the average rainfall is $<60 \mathrm{~mm} /$ month and classified as the rainy season when the average rainfall is $>60 \mathrm{~mm} /$ month. Meanwhile to the calculation of rainfall volume is done through the multiplication of precipitation rate and built areas. Rainfall volume in the study area is presented in Table 4 as follows

Table 4. Rain Volume in Built Areas on watersheds of Bandung Regency

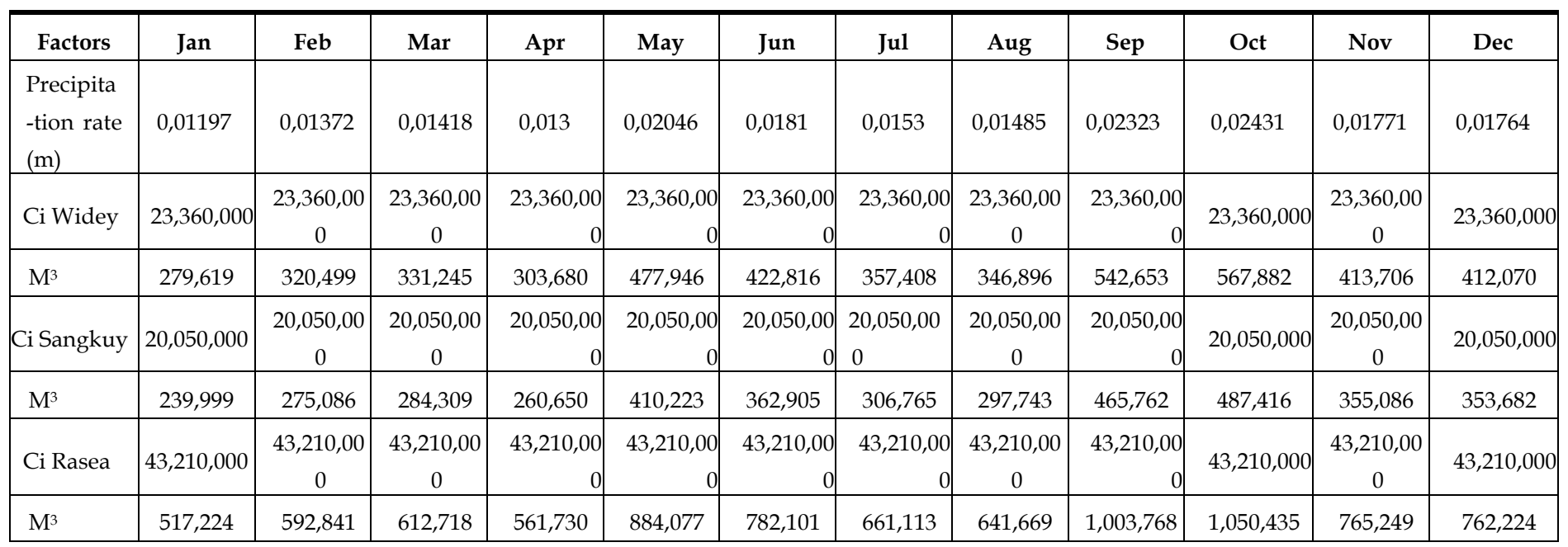




\begin{tabular}{|l|c|c|c|r|r|r|r|r|r|r|r|}
\hline Ci Tarik & $15,530,000$ & $\begin{array}{c}15,530,00 \\
0\end{array}$ & $\begin{array}{c}15,530,00 \\
0\end{array}$ & $\begin{array}{r}15,530,00 \\
0\end{array}$ & $\begin{array}{r}15,530,00 \\
0\end{array}$ & $\begin{array}{r}15,530,00 \\
0\end{array}$ & $\begin{array}{r}15,530,00 \\
0\end{array}$ & $\begin{array}{c}15,530,00 \\
0\end{array}$ & $\begin{array}{c}15,530,00 \\
0\end{array}$ & $\begin{array}{c}15,530,000 \\
15,530,00 \\
0\end{array}$ & $\begin{array}{c}15,530,000 \\
\mathrm{M}^{3}\end{array}$ \\
\hline
\end{tabular}

Table 4 shows that built areas potentially have a bigger surface runoff. Based on the calculation of ten years of length rainfall, it is most likely that the rainfall would be the same for the numbers of years ahead. The lowest surface runoff potentially occurred in $\mathrm{Ci}$ Tarik watershed with the amount of $185.894 \mathrm{~m}^{3}$ and the highest is in Ci Rasea watershed with the amount of 1.050.435 $\mathrm{m}^{3}$.

\section{Model of Infiltration Well}

If the volume and debit of surface runoff exceed the river capacity, the river would overflow as the result. The bigger the surface runoff amount is, the flood occurrence will be bigger too. In other words, flooding is caused by surface runoff. Therefore, to overcome the huge volume of a flood, the volume of surface runoff needs to be managed especially on rivers upstream and built areas. Management of surface runoff through rainwater ponds demands a large area and huge amount of budget, as well as the distance between built areas and the pond itself, will be far in the case of this study area, thus it turns out less effective. Thus, management of surface runoff should be done on the area where surface runoff occurred, especially on built areas. Therefore, rainfall on built areas whether it is settlements, buildings, industrial complexes, or public facilities is managed by absorbing rainwater onto infiltration wells. This management shall be done on each built area so that there will be no surface runoff on each built area unit.

Each type of built area, namely settlements, roads, and buildings, has a different width, therefore the volume of surface runoff is different as well. In this research, rainfall volume was forecasted by taking a house building as an example of a built area. The highest average precipitation rate is $0.02431 \mathrm{~m}(2.431 \mathrm{~mm})$ with the width measured on each multiplication being $10 \mathrm{~m}^{2}$. The projection of the built area's width and precipitation amount that needs to be absorbed is shown in Table 5.

Table 5. Rain volume needs to be absorbed

\begin{tabular}{|c|c|c|c|c|c|c|c|c|c|c|c|c|c|c|c|}
\hline Area $\left(\mathrm{m}^{2}\right)$ & 10 & 20 & 30 & 40 & 50 & 60 & 70 & 80 & 90 & 100 & 110 & 120 & 130 & 140 & 150 \\
\hline $\begin{array}{c}\text { Precipitatio } \\
\text { n rate }(\mathrm{m})\end{array}$ & \multicolumn{10}{|c|}{0,02431} \\
\hline Volume $\left(\mathrm{m}^{3}\right)$ & 0.24 & 0.49 & 0.73 & 0.97 & 1.22 & $\begin{array}{c}1.4 \\
6\end{array}$ & $\begin{array}{c}1.7 \\
0\end{array}$ & $\begin{array}{c}1.9 \\
4\end{array}$ & 2.19 & 2.43 & 2.67 & 2.92 & 3.16 & 3.40 & 3.65 \\
\hline & 160 & 170 & 180 & 190 & 200 & 210 & 220 & 230 & 240 & 250 & 260 & 270 & 280 & 290 & 300 \\
\hline $\begin{array}{c}\text { Precipitatio } \\
\text { n rate }(\mathrm{m})\end{array}$ & \multicolumn{10}{|c|}{0.02431} \\
\hline Volume & 2.83 & 3.01 & 3.19 & 3.36 & 3.54 & 3.72 & 3.89 & $\begin{array}{c}4.0 \\
7\end{array}$ & 4.25 & 4.42 & 4.60 & 4.78 & 4.96 & 5.13 & 5.31 \\
\hline
\end{tabular}

Table 5 shows that each built area needs to infiltrate water with the amount considered from the width of that built area. The aforementioned volume is calculated by the multiplication of precipitation rate and the width of built areas, either it is for settlements, roads, industrial complexes, or public facility buildings. The process of absorbing water is done through the installation of infiltration wells on each built area so that the occurring rainfall would not cause 
surface runoff.

The infiltration well model on house building, for example, is placed in the house yard or wasteland. If built areas are covering most of the land, then the infiltration well is installed beneath the ground surface with its flow directed to the well and the air hole should be built as well. The placement of infiltration well is exemplified in Figure 3

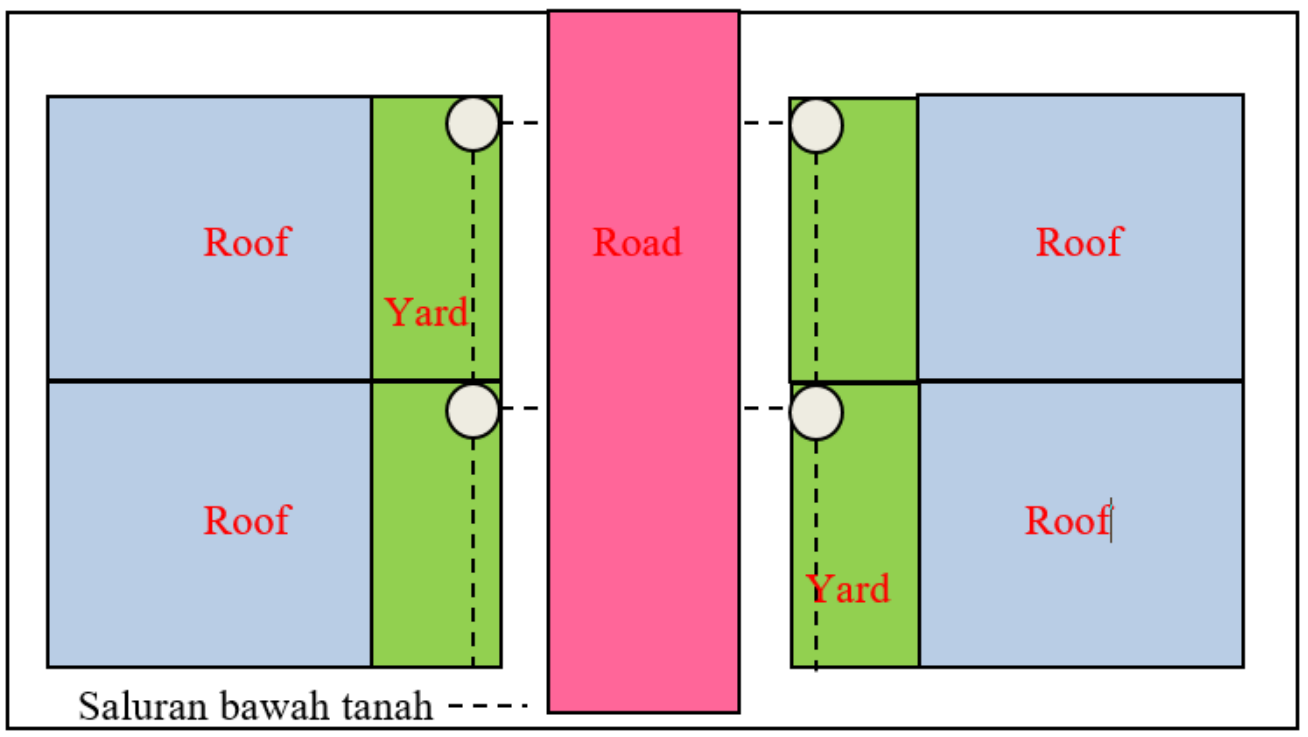

Figure 3. Placement of infiltration well (upper view)

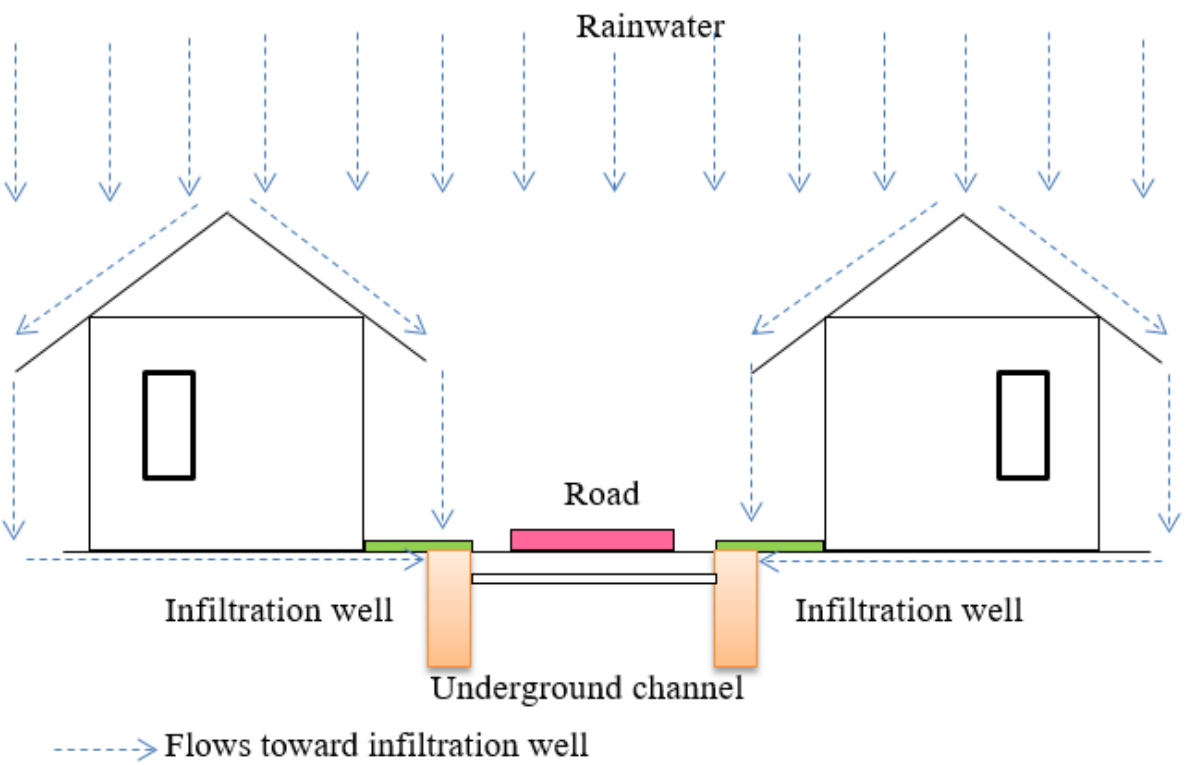

Figure 4. Placement of infiltration well (side view)

A house building set as an example in this research has a width of $90 \mathrm{~m}^{2}$. The rainfall volume needed to be absorbed is $2.19 \mathrm{~m}^{3}$. With that amount, the precipitated rainwater on that building flowed directly toward the infiltration well. The well used a drum placed inside a bordering wall with a depth of two meters, length of three rows of drum or 1.8 meters, and width of 0.7 meters to contain $2.52 \mathrm{~m}^{3}$ amount of rainwater. Based on the process done in this research, rainwater will not be inundated. The mentioned infiltration well is shown in Figure 4 

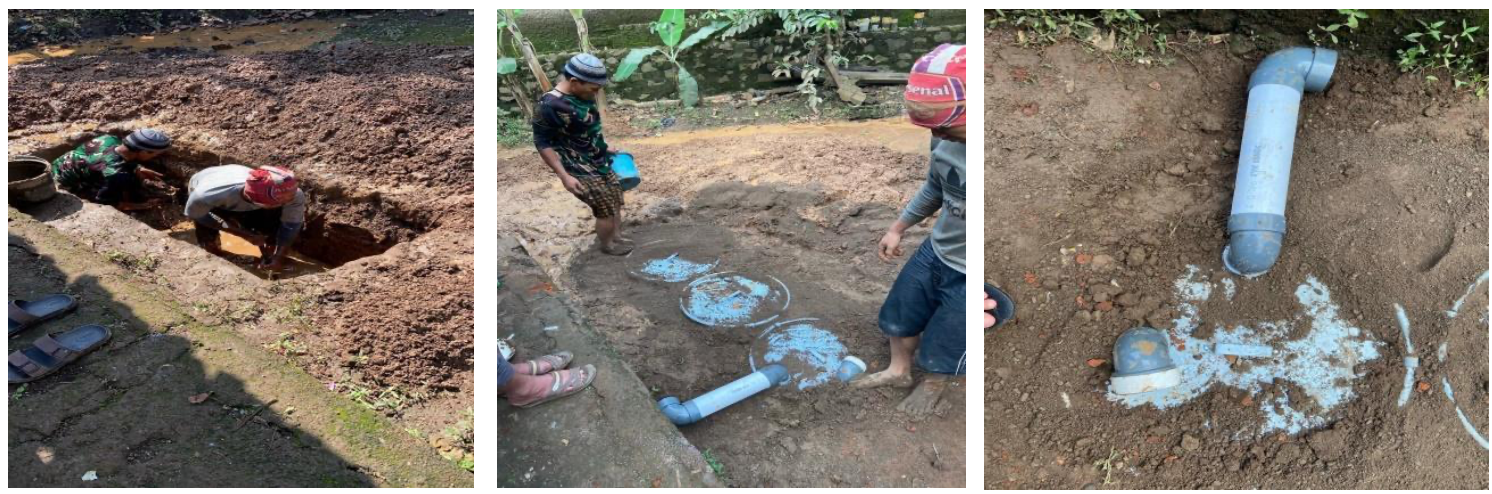

Figure 5. Infiltration well

With the forecasted highest average rainfall in October in the amount of $0.02431 \mathrm{~mm}$, this infiltration well could contain $2.52 \mathrm{~m}^{3}$ amount of rainwater, whereas the volume of rainwater precipitated on this house building is 2.19 $\mathrm{m}^{3}$. In the other words, this infiltration well can contain rainwater precipitated on the house building and surface runoff will not happen as a result.

\section{Discussion}

Land Use throughout Bandung Regency watersheds is dominated by agriculture and plantation land. Forests that have a function as catchment area have a width of $16.06 \%$ of $1785.52 \mathrm{~km}^{2}$ total width. Forest in Ci Tarik watershed has a width of $9.31 \% \quad\left(41.12 \quad \mathrm{~km}^{2}\right)$. Meanwhile built areas, namely settlements, roads, and public facility buildings have a width of $197.67 \mathrm{~km}^{2}$ $(11.07 \%)$ from $1382.13 \mathrm{~km}^{2}$. Built areas have a huge influence on the amount of surface runoff, in terms of whether the land will be permeable or not. The total width of built areas in four watersheds is; Ci Widey $22.36 \mathrm{~km}^{2}$, CiSangkuy $20.05 \mathrm{~km}^{2}$, Ci Rasea $43.21 \mathrm{~km}^{2}$, and Ci Tarik 68.59 $\mathrm{km}^{2}$.

Built areas are continuously expanding along with population growth and their activities on the river upstream, this has caused impermeable surfaces to expand as well. The expansion of built areas will increase surface runoff volume and debt. The management of surface runoff on built areas is done by installing infiltration wells. By the installation of infiltration wells on each built area, therefore rainwater will not be potentially turned into surface runoff.

The main factor that causes surface runoff is rainfall. The ten-year forecast of rain occurrence shows that high rainfall occurs from October to May with the highest in October. Rainfall that turns into the highest surface runoff occurred in October with the volume in each watershed as follows; Ci Widey surface runoff volume was $567,882 \mathrm{~m}^{3}$, Ci Sangkuy was $487,416 \mathrm{~m}^{3}$, Ci Rasea 1,050,435 $\mathrm{m}^{3}$, and Ci Tarik 377,534 $\mathrm{m}^{3}$. Surface runoff of four watersheds is as many as 2,483,267 $\mathrm{m}^{3}$ flows toward $\mathrm{Ci}$ Tarum. Surface runoff flows from each land use, especially on built areas and disembogues in Ci Tarum. This runoff is hardly managed when water-absorbent lands turn into impermeable surfaces. Thus, conservation activities need to be done by managing surface flows in built areas.

Management of surface flow can be done by providing absorbent land on built areas. Yet due to the changes of soil function which is impermeable, precipitated rainwater that is supposed to be absorbed turns into surface runoff. To manage surface runoff on built areas, an infiltration well is installed. The main function of an infiltration well is to contain rainwater proportional to the width of the built area.

Model of infiltration well should be adjusted to the width and precipitation 
rate, thus precipitated rainwater can be contained and absorbed onto the infiltration well. Built area, with a house building set as an example, which has the width of $90 \mathrm{~m}^{3}$ needs to absorb rainwater with the volume of $2,19 \mathrm{~m}^{3}$, therefore this infiltration well is designed to contain and absorb water with the mentioned volume. With the model of infiltration well on built areas, built areas will not be causing surface runoff as the result of rainfall.

\section{CONCLUSION}

Impermeable surfaces are caused by the conversion of lands into settlements, roads, industrial complexes, and public facility buildings. Based on Landsat 8 image analysis, built areas on four watersheds in Bandung Regency has a width of $197.67 \mathrm{~km}^{2}(19,01 \%)$. The span of built areas influences surface runoff volume.

The ten-year forecast of rainfall shows that the highest rainfall occurred in October. A precipitation rate of $0.02431 \mathrm{~m}$ $(2,431 \mathrm{~mm})$ that occurred in built areas of $197.67 \mathrm{~km}^{2}$ would then turn into surface runoff of 2,483,267 $\mathrm{m}^{3}$. This surface runoff flows into lower land with morphologically flat surfaces and is concentrated in locations like Dayeuhkolot, Baleendah, and Bojongsoang, thus $\mathrm{Ci}$ Tarum overflows and causes flooding.

Flood occurrence in Bandung Regency is caused by huge surface runoff and river overflow. For this reason, surface runoff needs to be well managed, especially in built areas. Management of surface runoff on built areas is done by containing and absorbing rainwater onto the infiltration well. With the installation of infiltration wells on each built area, then surface runoff can be managed.

\section{REFERENCES}

Ahiablame L, and Shakya R (2016). Modeling flood reduction effects of low impact development at a watershed scale. Journal of
Environmental Management, Vol. 171 , p. 81-91.

Amri U (2011). Globalisasi dan Dampaknya terhadap Lingkungan dan

Keamanan Manusia di Asia Pasifik: Kasus China dan Papua Nugini. Jurnal Kajian Wilayah, Vol. 2 (1), pp. 56-71.

Ardianto J, Barlian S, Dan Yulianto E (2015). Penanggulangan Banjir Sungai Melawi Dengan Tanggul. Vol. 1 (1), P. 1-11.

BANSAL N, MUKHERJEE M AND GAIROLA A (2015). CAUSES AND IMPACT OF URBAN FLOODING IN DEHRADUN.

INTERNATIONAL JOURNAL OF CURRENT RESEARCH. VOL.7 (2), PP.12615-12627.

Bianchin A and Bravin L (2008). Remote Sensing and Urban Analysis. Conference: Proceedings of the international conference on Computational Science and Its Applications, Part I, pp. 1-17.

Chen W, Zheng M, Gao Q, Deng C, Ma Y and Ji G (2021). Simulation of surface runoff control effect by permeable pavement. Water Science \& Technology, Vol. 83 (4), pp. 948-960.

Danáčová $M$, Valent $P$, and Výleta $R$ (2017). Evaluation of Surface Runoff Generation Processes Using a Rainfall Simulator: A Small Scale Laboratory Experiment. World Multidisciplinary Earth Sciences Symposium (WMESS 2017) IOP Conf. Series: Earth and Environmental Science 95, 022016, p. 1-8.

DINAS PU PENGAIRAN (2019). DATA CURAH HUJAN. BALAI PENGAIRAN, BANDUNG, JAWA BARAT.

Ibeje A.O, Osuagwu J.C and Onosakponome O.R (2018). A Markov Model for Prediction of Annual Rainfall. International Journal of Scientific Engineering and 
Applied Science (IJSEAS), Vol. 3 (11), p.1-5.

Ischak (2001). Urbanisasi dan Dampaknya Terhadap Lingkungan. Humaniora, Vol. 13 (3), pp. 275-283.

Iskandar D dan Sugandi D (2015). Flood Mitigation Efforts In The Capital Region of Jakarta. IJCS, Vol. 6(4),p. 685-696.

Lanrewaju A.F (2012).Urbanization, housing quality and environmental degeneration in Nigeria. Journal of Geography and Regional Planning, Vol. 5(16), pp. 422-429.

Maria R Dan Lestiana H (2014). Pengaruh Penggunaan Lahan Terhadap Fungsi Konservasi Airtanah Di Sub Das Cikapundung. Lembaga Ilmu Pengetahuan Indonesia 77. Jurnal Riset Geologi Dan Pertambangan (LIPI). Vol. 24 (2),Pp. 77-89.

Maulana R (2012). Kronik Banjir Bandung Selatan. Cita Citarum [online], avalaible at: citarum.org/infocitarum/berita-artikel/1103-kronikbanjir-bandung-selatan.html. accessed 1 July 2021.

Mireille N.M, Hosea M. Mwangi, John K. Mwangi, and John Mwangi Gathenya (2019). Analysis of Land Use Change and Its Impact on The Hydrology Of Kakia and Esamburmbur SubWatersheds of Narok County, Kenya. Hydrology, Vol. 6 (4), pp. 1-17.

Noeraga M.A.A, Yudana G, dan Rahayu P (2020). Pengaruh Pertumbuhan Penduduk Dan Penggunaan Lahan Terhadap Kualitas Air Bersih. Vol. 2 (1),Pp. 70 - 85.

Nofrizal (2019). Pengaruh Faktor Curah Hujan dan Aliran Permukaan Untuk Prognosa Debit dan Indek Banjir dalam Mengurangi Resiko Bencana Bahaya Banjir pada Daerah Dataran Banjir Aliran Sungai. Rangteknikjournal, Vol. 2 (2), Pp. 235-241.

Nuraeni R, Sitorus SRP, Panuju DR (2017). .Analisis Perubahan dan Arahan Penggunaan Lahan. Buletin Tanah dan Lahan, Vol. 1 (1), pp. 7985.
Raharja R.T (2012). Analisis Perubahan Penggunaan Lahan Dengan Menggunakan Aplikasi PJ dan SIG di Pesisir Kecamatan Sluke Kabupaten Rembang Tahun 2004-2012. Skripsi, Fakultas Geografi Universitas Muhammadiyah Surakarta.

Rai M.S (2017). Impact of Urbanization on Environment International Journal on Emerging Technologies. Vol. 8(1),pp.127-129.

Sarbidi (2015). Metoda Penerapan Zero Run Offpada Bangunangedung Dan Persilnyauntuk Peningkatan Panen Air Hujan Dan Penurunan Puncak Banjir. Jurnal Permukiman, Vol. 10 (2),Pp. 106-117.

Sugandi D (2014). A Model Of Environmental Conservation for Sagara Anakan," International Journal Of Conservation Science, vol. 5 (1), p. 95-106.

Sugandi D and Pascawijaya R, (2020). Decreasing The Surface Run-Off Through Rainfall absorption In The Bandung Basin, Indonesia. Journal of Environment Hydrology, Vol. 28 (2), p. 1-12.

Sugandi D and Pascawijaya R (2020). The Life Patterns Of Sinarresmi Community In Adjusting To Environment Of Landslide Prone. International Journal of Conservation Science, vol. 11 (3), hal. 747-756.

Suprayogi S, Fatchurohman H, and Widyastuti M (2019). Analisis Kondisi Hidrologi terhadap Perkembangan Wilayah Perkotaan Studi Kasus DAS Kali Belik Yogyakarta. Jurnal Geografi, Universitas Gadjah Mada, Vol. 16(2),p. 145-161., Vol. 6(4),p. 685-696

Susiati H dan Subagio H (2016). Aplikasi Penginderaan Jauh Dalam Pemetaan Penggunaan Lahan Detil Tapak RDE, PUSPIPTEK Serpong. Jurnal Pengembangan Energi Nuklir. Vol. 18 (2),pp. 101-112.

Teo H.C, Lechner A.M, Grant W, Chan F.K.S, Cheshmehzang A, Tan- 
Mullins M, Chan H.K, Sternberg T, Arceiz A.C (2019). Environmental Impacts of Infrastructure Development under the Belt and Road Initiative. Environments, Vol. 6, 72, pp. 1-22.

Tjiptoherijanto P (1999). Urbanisasi dan Perkembangan kota di Indonesia. Populasi, Vol. 10 (2), pp. 57-72.

Vardoulakis S, Dear K dan Wilkinson P (2016). Challenges and Opportunities for UrbanEnvironmental Health and Sustainability:the HEALTHY-POLIS initiative. Journal of Environment Health. 15 (1), pp. 1-4.

Ali Wijaya dan Cahyono Susetyo (2017). Analisis Perubahan Penggunaan Lahan di Kota Pekalongan Tahun 2003, 2009, dan 2016. Jurnal Teknik ITS. Vol. 6 (2), pp. C415-C417. 